Article

\title{
Kramecyne - A New Anti-inflammatory Compound Isolated from Krameria cytisoides
}

\section{Salud Pérez-Gutiérrez, Ernesto Sánchez-Mendoza, Diana Martínez-González, Miguel Angel Zavala-Sánchez and Cuauhtemoc Pérez-González *}

Departamento de Sistemas Biológicos, Universidad Autónoma Metropolitana-Xochimilco, Calzada del Hueso 1100, Col. Villa Quietud, Coyoacan C.P. 04960, D.F.A.P. 23-181, Mexico

* Author to whom correspondence should be addressed; E-Mail: cperezg@correo.xoc.uam.mx.

Received: 13 February 2012; in revised form: 13 February 2012 / Accepted: 14 February 2012 / Published: 20 February 2012

\begin{abstract}
In the present work we describe the structure and anti-inflammatory activity of a new compound, kramecyne, isolated from a methanol extract of Krameria cytisoides (Krameriaceae). The structure of kramecyne was determined by IR, NMR, MS, and elemental analysis, which indicated that the structure corresponded to a hexamer of cyclic peroxide monomers. This compound exhibited good anti-inflammatory activity in the 12-O-tetradecanoylphorbol-13-acetate (TPA)-induced mouse ear edema $(51.8 \pm 6.9 \%$ inhibition) and carrageenan-induced rat paw edema models at doses of $50 \mathrm{mg} / \mathrm{kg}$. The compound significantly reduced edema to $63.1 \%$ after $1.0 \mathrm{~h}$, and the effect was unchanged for $5 \mathrm{~h}$. Kramecyne did not present acute toxicity, even at doses of 5,000 $\mathrm{mg} / \mathrm{kg}$.
\end{abstract}

Keywords: anti-inflammatory activity; Krameria; peroxide; polymer; kramecyne

\section{Introduction}

Inflammatory diseases are an important cause of human mortality and morbidity. Many diseases are associated with inflammation, including infections by bacteria, viruses, and protozoa, and autoimmune diseases, such as arthritis, diabetes, Alzheimer's, and cancer. Inflammation is typically treated using non-steroidal anti-inflammatory drugs (NSAIDs) and corticosteroids, but the secondary effects can be significant.

Many plants have been used in traditional medicine to prevent or minimize the progression of inflammation. Krameria cytisoides Cav (Krameriaceae) is a perennial erect shrub found across the 
Americas. It is typically up to $1.8 \mathrm{~m}$ in height, obovate leaves up to $2 \mathrm{~cm}$ long, purplish flowers, $2 \mathrm{~cm}$ long sepals. The plant is used in Mexican traditional medicine to treat diarrhea, hemorrhoids, sore throat, sore gums, and sore nipples [1], and it is effective for inflammations of the genitalia. It is also taken for urinary tract problems and painful rectal conditions [2], and the root is used to treat stomach and bowel cancer inflammatory diseases [3]. Twenty-one lignans, neolignans, and norneolignans have been isolated from the roots [4], but the anti-inflammatory activities of this plant and its extracts have not previously been examined.

In this study we reported the structure of a cyclic peroxide named kramecyne which has been isolated for the first time from the methanol extract of $K$. cytisoides; the anti-inflammatory properties of this compound were also tested on two models in vivo and acute toxicity was determined.

\section{Results and Discussion}

The optical rotation of kramecyne was $[\alpha]^{20}=36.9^{\circ}$, and the IR data were $\left(v, \mathrm{~cm}^{-1}\right.$ solid): 3,332 (O-H), 2,919 and 2,486 (C-H), 1,608 (skeleton), 1,443 (C-C), 1,284, 1,108 (C-O), and 800 (O-O) [5]. The molecular weight was obtained from a positive FAB-MS, which indicated protonated molecular $[\mathrm{M}+\mathrm{H}]^{+}$ions at $m / z 793,[(\mathrm{M} / 2)+\mathrm{H}]^{+}$at 397 , and $[(\mathrm{M} / 6)+4 \mathrm{H}]^{+}$at 136 . Elemental analysis showed that the molecule contained $\mathrm{C} 45.23, \mathrm{H} 6.02$, O 48.23\%. The combined molecular weight and elemental analysis data provided a molecular formula of $\mathrm{C}_{30} \mathrm{H}_{48} \mathrm{O}_{24}$.

\subsection{NMR Studies}

${ }^{1} \mathrm{H},{ }^{13} \mathrm{C}$, DEPT, gCOSY, gHSQC, and gHMBC NMR spectra were recorded in a methanol- $\mathrm{d}_{4}$ solution, and all NMR data are reported in Table 1 . The NMR- ${ }^{1} \mathrm{H}$ spectrum showed a signal overlap at $\delta=3.58$ and $3.82 \mathrm{ppm}$, and the chemical shifts were typical of aliphatic protons vicinal to the oxygen [6]. The ${ }^{13} \mathrm{C}$-NMR spectrum presented five signals at $\delta_{13 \mathrm{C}} 62.12,62.85,63.40,73.17$, and $75.15 \mathrm{ppm}$. These chemical shifts confirmed that each carbon was bonded to oxygen.

Table 1. NMR spectroscopy data for kramecyne (500 MHz, methanol- $\left.\mathrm{d}_{4}\right)$.

\begin{tabular}{llll}
\hline Position & $\boldsymbol{\delta}_{\mathbf{C}}$, type & $\boldsymbol{\delta}_{\mathrm{Ha}}, \boldsymbol{m u l t}(\boldsymbol{J}$ in $\mathbf{H z})$ & $\boldsymbol{\delta}_{\mathrm{Hb}}, \operatorname{mult}(\boldsymbol{J}$ in $\mathbf{H z})$ \\
\hline 3 & $63.40, \mathrm{CH}_{2}$ & $3.61, \mathrm{~d}(11.47)$ & $3.63, \mathrm{~d}(11.47)$ \\
4 & $75.15, \mathrm{C}$ & - & - \\
5 & $73.17, \mathrm{CH}$ & $3.74, \mathrm{dd}(-, 3.19)$ & - \\
6 & $62.12, \mathrm{CH}_{2}$ & $3.69, \mathrm{~m}$ & $3.78, \mathrm{dd}(10.54,3.19)$ \\
7 & $62.85, \mathrm{CH}_{2}$ & $3.63, \mathrm{~d}(11.50)$ & $3.67, \mathrm{~d}(11.50)$ \\
\hline
\end{tabular}

The number of peaks in the ${ }^{13} \mathrm{C}$-NMR spectrum and the integration values in the ${ }^{1} \mathrm{H}-\mathrm{NMR}$ spectra suggested that the molecule was highly symmetric. According to the molecular weight and the number of carbons, we propose that the $\mathrm{C}_{30} \mathrm{H}_{48} \mathrm{O}_{24}$ molecule is a cyclic polymer (Figure 1a) composed of six monomers of formula $\mathrm{C}_{5} \mathrm{H}_{8} \mathrm{O}_{6}$ (Figure $1 \mathrm{~b}$ ). The monomers are linked by formation of a cyclic ether between atoms $4-9$ [6]. 
Figure 1. (a) Kramecyne (cyclic polymer); (b) Monomer.

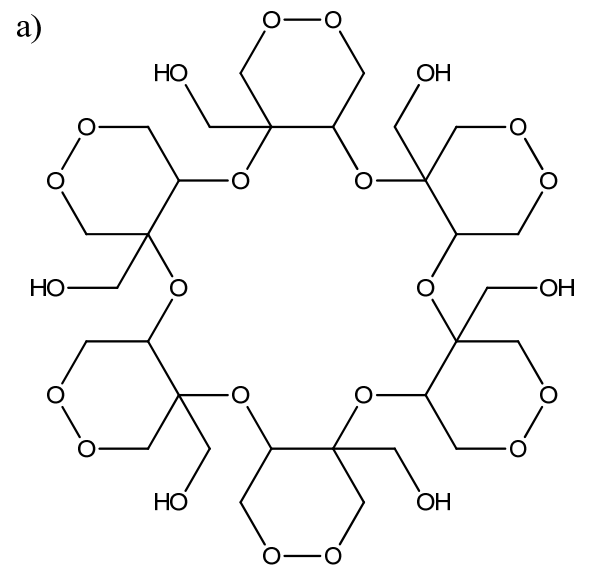

b)

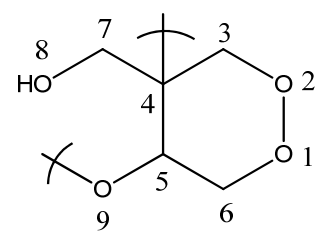

The DEPT spectrum was helpful in the elucidation the types of $\mathrm{C}$ atoms and showed that each monomer included three $\mathrm{CH}_{2}$, one $\mathrm{CH}$, and one quaternary carbon. Each monomer was a cyclic peroxide with a hydroxymethylene and an ether groups. The correlations between protons and carbons were assigned based on an analysis of the gCOSY and gHSQC NMR spectra, the values of which are reported in Table 1. The structural position of the quaternary carbon was confirmed from the gHMBC NMR correlations.

The three-dimensional structure of kramecyne (Figure 2) was optimized using a DFT approach [7] with the B3LYP/6-31G method level of approximation. The vibrational frequencies were real, indicating that the structure assumed a minimum energy conformation [8]. The optimized geometry was used to predict the theoretical ${ }^{1} \mathrm{H}-\mathrm{NMR}$ and ${ }^{13} \mathrm{C}$-NMR spectra. The spectra calculated using the ACD Labs package agreed well with the experimental data (see Table 1). The ${ }^{13} \mathrm{C}-\mathrm{NMR}$ spectrum included peaks at $\delta 64.10,65.10,68.05,76.69$, and $80.08 \mathrm{ppm}$. The chemical shifts of the protons were predicted from theory to occur between $\delta 3.55$ and $\delta 4.35 \mathrm{ppm}$. A comparison between the ${ }^{1} \mathrm{H}-\mathrm{NMR}$ experimental and calculated spectra revealed the same signal patterns.

Figure 2. Kramecyne. The 3D structure was optimized at the B3LYP/6-31G level of theory.

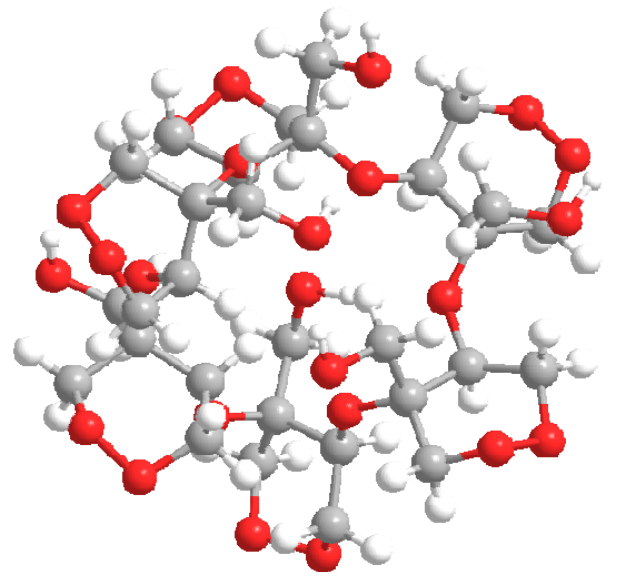

Figure 3 shows a three-dimensional optimized structure of the monomer, in which the H3 and H6 methylene protons were present in the equatorial and axial conformations. This conformation was well-defined by the conformational restraints of the cyclic peroxide. The H7 protons were not 
equivalent because they could not be interchanged by a symmetry operation in any conformation [7]. HSQC experiments confirmed that the methylene protons were diastereotopic and, therefore, provided different chemical shifts.

Figure 3. 3D structure of kramecyne monomer.

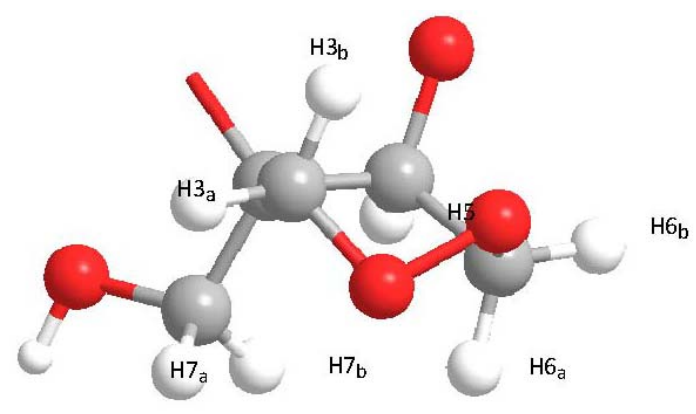

\subsection{Kramecyne Acetate}

The ${ }^{1} \mathrm{H}-\mathrm{NMR}$ and ${ }^{13} \mathrm{C}-\mathrm{NMR}$ spectra showed that the O-O bond of the peroxide reacts with the $\mathrm{Ac}_{2} \mathrm{O}$, resulting in the formation of two additional acetic ester moieties and the third acetate group by the hydroxyl group reaction. The polymeric cyclic structure is maintained during the acetylation reaction and included 18 acetate groups, which is confirmed by the APCI-MS spectrum that showed $m / z=1,566.6$, corresponding to $[\mathrm{M}+\mathrm{H}]$, but due to the symmetry of this structure the ${ }^{13} \mathrm{C}-\mathrm{NMR}$ spectrum only showed three signals of carbonyl groups.

The ${ }^{13} \mathrm{C}$-NMR spectrum presented three carbonyl groups at $\delta 169.54,170.29$, and $170.50 \mathrm{ppm}$, and the carbons of the monomer have signals at $\delta 62.02,64.15,64.35,71.15$, and $73.45 \mathrm{ppm}$. The ${ }^{1} \mathrm{H}-\mathrm{NMR}$ spectrum also confirmed the successful acetylation. All monomer signals were deshielded by the three ester groups, the protons of which yielded peaks at $\delta 4.18,4.55$, and $5.30 \mathrm{ppm}$, and the three methyl groups, with peaks at $\delta 2.1,2.2$, and $2.3 \mathrm{ppm}$.

\subsection{Anti-inflammatory Activity}

The anti-inflammatory activity of chloroform and methanol extracts on TPA-induced ear edema was tested next; the chloroform extract did not show any activity on this model, so we followed the study with the methanol extract, which had a significant effect (50.7 $\pm 3.2 \%$ inhibition).

The anti-inflammatory activity of kramecyne on TPA-induced ear edema was also tested. At a dose of $2 \mathrm{mg} / \mathrm{ear}$, this compound showed significant activity $(51.8 \pm 6.9 \%$ inhibition), similar to that obtained with indomethacin $(64.8 \pm 5.8 \%$ inhibition $)$. The pronounced inflammation induced by TPA when is administered topically is thought to be mediated by protein kinase $\mathrm{C}$, and the stimulation of phospholipase $\mathrm{A}_{2}$, and cyclooxygenase [10], which results in the release of arachidonic acid and prostaglandin $\mathrm{E}_{2}$ [11]. Thus, both phospholipase $\mathrm{A}_{2}$ and cyclooxygenase inhibitors are active in this model for inflammation, and kramecyne may interfere with these mediators to inhibit TPA-induced inflammation.

Kramecyne, tested in vivo, showed significant activity on carrageenan-induced inflammation relative to the control group (Table 2). This compound had no activity at doses of 200 and $400 \mathrm{mg} / \mathrm{kg}$ $4 \mathrm{~h}$ after carrageenan injection. However, at a dose of $50 \mathrm{mg} / \mathrm{kg}$, kramecyne significantly reduced 
inflammation by $63.1 \%$ after $1 \mathrm{~h}$, and the effect was unchanged during the following $5 \mathrm{~h}$. At this dose, kramecyne showed the best effects, and at dose of $25 \mathrm{mg} / \mathrm{kg}$ showed a similar effect to indomethacin after $5 \mathrm{~h}$, although with this dose there is no activity after $1 \mathrm{~h}$. Two hours after administering at a dose of $100 \mathrm{mg} / \mathrm{kg}$, the inflammation was reduced to $70.1 \%$, and after $3 \mathrm{~h}$ the inhibition was $46.9 \%$, the inhibition effect of kramecyne is not dose dependent (Table 2). Although the indomethacin dose is lower than that of kramecyne; the $\mathrm{LD}_{50}$ of indomethacin in rats is $13 \mathrm{mg} / \mathrm{kg}$ [12], while it was not possible to determine the $\mathrm{LD}_{50}$ of kramecyne because this compound has no toxicity at a dosis of $5,000 \mathrm{mg} / \mathrm{kg}$.

Table 2. Anti-inflammatory activity of kramecyne on carrageenan-induced edema.

\begin{tabular}{|c|c|c|c|c|c|c|}
\hline \multirow{3}{*}{$\underset{\text { h }}{\text { Time }}$} & \multirow{3}{*}{$\begin{array}{c}\text { Indomethacin } \\
8 \mathrm{mg} / \mathbf{k g}\end{array}$} & \multicolumn{5}{|c|}{ (\% inhibition) } \\
\hline & & \multicolumn{5}{|c|}{ Kramecyne } \\
\hline & & $25 \mathrm{mg} / \mathrm{kg}$ & $50 \mathrm{mg} / \mathrm{kg}$ & $100 \mathrm{mg} / \mathrm{kg}$ & $200 \mathrm{mg} / \mathrm{kg}$ & $400 \mathrm{mg} / \mathrm{kg}$ \\
\hline 1 & $26.4 \pm 2.1 *$ & $17.5 \pm 13.04$ & $63.1 \pm 12.1 *$ & $52.2 \pm 6.1 *$ & $58.6 \pm 6.4 *$ & $42.5 \pm 11.1 *$ \\
\hline 2 & $30.0 \pm 4.5 *$ & $30.8 \pm 8.24$ & $55.7 \pm 5.6 *$ & $70.1 \pm 5.7 *$ & $36.9 \pm 6.3 *$ & $41.7 \pm 6.8 *$ \\
\hline 3 & $63.1 \pm 7.1 *$ & $40.5 \pm 5.54$ & $51.4 \pm 5.5 *$ & $46.9 \pm 5.8 *$ & $29.9 \pm 4.6$ & $33.1 \pm 5.9$ \\
\hline 4 & $68.3 \pm 8.1 *$ & $46.1 \pm 4.05 *$ & $56.4 \pm 4.2 *$ & $43.2 \pm 2.7$ & $24.9 \pm 5.5$ & $28.6 \pm 5.0$ \\
\hline 5 & $67.6 \pm 6.6 *$ & $60.1 \pm 4.09 *$ & $64.5 \pm 4.1 *$ & $45.2 \pm 5.1$ & $21.2 \pm 4.9$ & $19.9 \pm 2.7$ \\
\hline
\end{tabular}

Results are expressed as percentage of inhibition and mean of eight determinations $\pm \mathrm{SE}$. ANOVA one way, Tuckey test $* p<0.05$ for comparison of kramecine with indomethacin treated groups.

Leukocyte migration to an injured tissue is an important aspect of the inflammatory process. The release of several mediators of the phlogistic response, including histamine and serotonin, are responsible for the immediate inflammation response [13], whereas kinins and prostaglandins mediate the prolonged response [14] On the other hand, some plant constituents significantly inhibit the biosynthetic pathways of inflammation mediators [14]. Kramecyne showed effects against this model, suggesting that its anti-inflammatory activity was possibly due to inhibition of the production of these mediators.

Kramecyne did not present acute toxicity, even at the highest studied doses $(5,000 \mathrm{mg} / \mathrm{kg})$. No damage in the liver, lung, heart and kidney was observed. Kramecyne thus presents very low toxicity in the model test, but it is necessary to carry out more experiments for chronic toxicity evaluation. This low toxicity opens the possibility of using this compound in the treatment of inflammatory diseases. Experiments are in progress to further evaluate the molecular mechanism through which kramecyne exerts its anti-inflammatory activity.

\section{Experimental}

\subsection{General}

The mass spectrum was recorded using the Fast Atom Bombardment (FAB) ionization method in the positive mode by direct injection on a Jeol-102 mass spectrophotometer, using a nitrobenzyl alcohol-like matrix. Elemental analysis was conducted using an Exeter Analytical Inc. CE-440 elemental analyzer, and acetanilide was used as the reference compound. The IR spectrum was recorded in the solid phase using a Perkin-Elmer Paragon 1000 FT-IR spectrophotometer. All NMR 
spectra were recorded at $298 \mathrm{~K}$ on a Bruker Avance DMX500 spectrometer operated at 500.13309 $\mathrm{MHz}$ for ${ }^{1} \mathrm{H}-\mathrm{NMR}$ and $125.77036 \mathrm{MHz}$ for ${ }^{13} \mathrm{C}-\mathrm{NMR} .{ }^{1} \mathrm{H}$ - and ${ }^{13} \mathrm{C}-\mathrm{NMR}$ chemical shifts were reported relative to TMS and $\mathrm{CDCl}_{3}$, respectively, and compound was dissolved in methanol- $\mathrm{d}_{4}$. The DEPT, gCOSY, gHSQC, and gHMBC spectra were measured using the standard Bruker pulse sequences. The kramecyne acetate was dissolved in $\mathrm{CDCl}_{3}$, and the chemical shifts were reported with respect to TMS and $\mathrm{CDCl}_{3}$.

\subsection{Plant Material}

K. cytisoides was collected in Las Comadres Municipality of Guadalcazar, San Luis Potosi State, Mexico, in June 2009. The taxonomic identification of the plant was confirmed by taxonomist José García Pérez. A voucher specimen (SPLM44560) was deposited in the Isidro Palacios Herbarium of the Universidad Autónoma de San Luis Potosí.

\subsection{Isolation of Kramecyne}

The shade-dried leaves of $K$. cytisoides were reduced to powder, then a portion (200 g) were defatted with hexane $(2 \mathrm{~L})$ at boiling point for $4 \mathrm{~h}$, and then the material was extracted into $\mathrm{MeOH}$ $(2 \mathrm{~L})$ under reflux for $4 \mathrm{~h}$. The methanol extract was concentrated to half the original volume under reduced pressure, and a dark brown solid was obtained in $3 \%$ yield (m.p. $172{ }^{\circ} \mathrm{C}$, dec.). The compound's purity was determined by thin-layer chromatography, ${ }^{1} \mathrm{H}-\mathrm{NMR}$ and ${ }^{13} \mathrm{C}-\mathrm{NMR}$ spectra.

\subsection{Kramecyne Acetate}

A solution of kramecyne $(100 \mathrm{mg})$ and pyridine $(2 \mathrm{~mL})$ was acetylated with $\mathrm{Ac}_{2} \mathrm{O}(3.5 \mathrm{~mL})$ at room temperature overnight. After the usual workup, the crude product was purified by silica gel chromatography. The triacetate obtained had a mp of $125-127^{\circ} \mathrm{C}$.

\subsection{Detection of Peroxides}

Twenty milligrams of the compound were dissolved in methanol, a few drops of a 5\% potassium iodide solution were added, and the solution was shaken. The appearance of a yellow-to-brown color indicated the presence of peroxides [15].

\subsection{Animals}

Male Wistar Rats (150-200 g) and male mice of the CD1 strain (20-25 g) from the Universidad Autónoma Metropolitana-Xochimilco animal facility were housed in isolated cages at $24{ }^{\circ} \mathrm{C}$ under a light-dark cycle of 12:12. The animals were supplied with food (Purina) and water ad libitum.

\subsection{2-O-Tetradecanoylphorbol-13-acetate (TPA)-Induced Mouse Ear Edema}

The model for TPA-induced edema in mouse ears has been described previously [16]. A solution containing TPA $(2.5 \mu \mathrm{g})$ in acetone $(25 \mu \mathrm{L})$ was topically applied to the inner and outer surfaces of the right ears of male CD1 mice, and acetone alone was applied to the inner and outer surfaces on the left 
ear. Thirty minutes thereafter, kramecyne or indomethacin $(2.0 \mathrm{mg})$ dissolved in acetone were topically applied to the right ear and acetone was applied to the left ear six hours later, the animals were sacrificed, and $6 \mathrm{~mm}$ plugs of the central portion of both ears were weighed. The percentage inhibition of edema was determined.

\subsection{Carrageenan an Induced Rat Paw Edema}

Paw edema was induced by intradermal injection of $0.1 \mathrm{~mL}$ of a $1 \%$ carrageenan suspension in the left hind foot pad. One hour prior to carrageenan injection, groups of eight rats each were treated with $25,50,100,200$, or $400 \mathrm{mg} / \mathrm{kg}$ kramecyne. The control rats received the vehicle alone (polyvinyl pyrrolidone, PVP) and the reference group received $8 \mathrm{mg} / \mathrm{kg}$ indomethacin, the administration was orally. The paw volume was measured by the volume displacement method using a plethysmometer (Ugo Basile) 1.0, 2.0, 3.0, 4.0, and 5.0 h after carrageenan administration. The percentage of edema inhibition was determined [17].

\subsection{Acute Toxicity}

Kramecyne was orally administered as a single dose to groups of mice $(n=3)$ at different concentrations $(1,000-5,000 \mathrm{mg} / \mathrm{kg})$. The dose ranges used in mice followed the method of Lorke [17]. After administration, the animals were observed under open-field conditions for a $72 \mathrm{~h}$ period; the animals were sacrificed and were observed damage of heart, lung, liver and kidney. The number of animal deaths and signs of clinical toxicity were recorded in this period.

\subsection{Statistical Analysis}

Data are expressed as mean \pm S.E.M. Statistical analysis was performed using the Student's t-test $(\mathrm{P}<0.05)$, while ANOVA followed by Tukey test $\mathrm{P}<0.05$ were considered as indicative of significance.

\section{Conclusions}

From the methanol extract of $K$. cytisoides a new cyclic peroxide composed of six monomers was obtained. The structure was characterized by different spectroscopical methods. Kramecyne had anti-inflammatory activity in the acute inflammation models used in this work when administered topical and orally, and it showed low acute toxicity.

\section{Acknowledgments}

We acknowledge the financial support of the Instituto de Ciencia y Tecnología del Distrito Federal (project number 3410766).

\section{References and Notes}

1. Healt. Available online: http://www.innvista.com/health/herbs/default.htm (Accessed on 23 January 2012). 
2. Rhatany. Available online: http://www.innvista.com/healt/herbs/rhatany.htm (Accessed on 23 January 2012).

3. Martínez, M. Las Plantas Medicinales de México; Ediciones Botas: México D.F., México, 1995; p. 90.

4. Achenbach, H.; Grob, J.; Dominguez, X.A.; Cano, G.; Verde, S.J.; Brussolo, L.D.C.; Muñoz, G.; Salgado, F.; López, L. Lignans, neo-lignans and norneolignans from Krameria cystisoides. Phytochemistry 1987, 26, 1159-1166.

5. Pretsch, E.; Bühlmann, P.; Badertscher, M. Structure Determination of Organic Compounds. Tables of Spectral Data. Fourth, Revised and Enlarged, 4th ed.; Springer-Verlag: Berlin/Heidelberg, Germany, 2009; pp. 69-162.

6. Günther, H. NMR Spectroscopy. Basic Principles, Concepts and Applications in Chemistry; John \& Sons: Hoboken, NJ, USA, 1995; pp. 69-132.

7. Koch, W.; Holthausen, M.C. A Chemist's Guide to Density Functional Theory; Wiley-VCH: Weinheim, Germany, 2000; pp. 117-134.

8. Frisch, M.J.; Trucks, G.W.; Schlegel, H.B.; Scuseria, G.E.; Robb, M.A.; Cheeseman, J.R.; Montgomery, J.A., Jr.; Vreven, T.; Kudin, K.N.; Burant, J.C.; et al. GAUSSIAN 03, Revision C.02, Gaussian, Inc., Wallingford, CT, USA, 2004.

9. Füstenberger, G.; Richter, H.; Fusening, N.E.; Marks, F. Arachidonic acid and prostaglandin E2 release and enhaced cell proliferation induced by the phorbol ester TPA in a murine epidermal cell line. Cancer Lett. 1981, 11, 191-198.

10. Ashendel, C.L.; Boutwell, R.K. Direct measurement of specific binding of highly lipohpilic phorbol diester to mouse epidermal membranes using cold acetone. Biochem. Biophys. Res. Commun. 1981, 543-549.

11. Crunkhon, P.; Meacock, B.K. Mediators of the anti-inflammatory, analgesic and antipyretic effects of an aqueous extract of Erythraea centarium. Planta Medica 1971, 57, 34-37.

12. Budavari, S. The Index Merck; Merck \& Co.: Rahway, NJ, USA, 1989, p. 787.

13. Antonio, M.A.; Brito, A.R.M.S. Oral anti-inflammatory and inti-ulcerogenic activities of a hydroalcoholic extract and partitioned fractions of Turnera ulmifolia (Turneraceae). J. Ethnopharmacol. 1998, 61, 215-228.

14. Speroni, E.; Cervellati, R.; Innocenti, G.; Costa, S.; Guerra, M.C.; Dall Acqua, S.; Govoni, P. Anti-inflmmatory, anti-nociceptive and antioxidant activities of Balanites aegyptiaca (L) Delile. J. Ethnopharmacol. 2005, 98, 117-125.

15. Kelly, J.R. Review of Safety Guidelines for Peroxidizable Organic Chemicals; Eastman: Kingsport, TN, USA, 1997; p. 8.

16. Young, J.M.; de Young, L.M.; Kheifets, J.B.; Ballaron, S.J. Edema and cell infiltration in the phorbol ester treated mouse ear are temporally separate and can be differentially modulated by pharmacologic agents. Agents Actions 1989, 26, 335-341.

17. Olajide, A.O.; Olubusayo, A.S.; Modupe, M.J.; Ekhelar, A.I.; Olusola, A.; Morebise, N.; Okpako, D.T. Studies on the anti-inflamatory, antipyretic and analgesic properties of Alstonia boonei stem bark. J. Ethnopharmacol. 2000, 71, 179-186. 
18. Lorke, D. A new approach to practical acute toxicity testing. Arch. Toxicol. 1983, 54, 275-287.

Sample Availability: Samples of the compound is available from the authors.

(C) 2012 by the authors; licensee MDPI, Basel, Switzerland. This article is an open access article distributed under the terms and conditions of the Creative Commons Attribution license (http://creativecommons.org/licenses/by/3.0/). 